

\title{
Whiteness, Smoothing and the Origin of Samoan Architecture'
}

\author{
Albert L. Refiti
}

\section{Introduction}

In Samoa, architecture arises from the directive to house the ancestors, ${ }^{2}$ who are presumed to inhabit everything, everywhere, simultaneously. Architecture's ritual performance plays important roles in demarcating and ordering space relative to the ancestors' occupation in time and, at the same time, en-abling a technical apparatus that makes possible a becoming-ancestor. In this context, how does Samoan architecture relate to the tenet that architecture continually returns "as guarantee of renewal: not only as a token from the past but as a guide to the future" (Rykwert, 1981: 191)?

Rykwert's text interprets humanity's ability to "build or adopt enclosures [and] ... take possession of enclosed volumes" as a will to 'return' to origins. The latter can be witnessed in the psychological development of children: when at play, they turn tables and chairs into "a 'cozy place' for making a 'home'," a manifestation, perhaps, of a desire for the mother's womb (191-2). Rykwert believes that this desire to 'return' is directed by the "memory of something which cannot but be lost" (14), a notion and not a thing, which is why he refers to this place as Paradise: "a promise as well as a memory" (192). The proposition, then, is that the primitive hut is continually made and remade, in our desire to rediscover our original state, and brings a sense of renewal. The promise of Paradise reaffirms our existence in the present. One could say that 'forgetfulness' and 'return' combine in Western thought to imprison the ancients forever in Paradise, suspending them in mist: mythos. ${ }^{3}$

To analyse Samoan architecture through Rykwert's return to (lost) origins is problematic. Any concept of time that poses the past, present and future as separate moments is incompatible with Samoan thinking. The ancestors do not recede into a lost time: in fact, as will be shown below, they are continually available. The question of origins in Samoan thought and, by extension, architecture, is always a question of becoming, a question of the ancestors' weaving and making of time.

This paper sets out to explore how Samoan architecture and craft operate by fashioning material things: they are stripped (olo) and organised (teu) towards a 'whiteness' (sina or malama), because they are to be placed before the ancestors, who are continually present via the circle of fa'amatai. ${ }^{4}$ The paper explores Samoan thought ${ }^{5}$ regarding the genealogy of beings existing within the matai system, to develop new insights into the discourse on 'origins' and architecture's role in Samoa and the Pacific generally.
I. I would like to acknowledge Tina Engels-Schwarzpaul whose expert editing helped shape this paper into a manageable article. The paper is dedicated to my late father, Palaiali'i Fotuoa'ana Falani Refiti.

2. See Buck (1930: 52), Tofaeono (2000: 32-33), Allen (1993: 49) and Tcherkézoff (2005: 256-257). I refer specifically here to the faletele (oval council house) and the faleafolau (long council house) because they are made to the configurations of the fono council of the fa'amatai and are generally accepted as the first order of Samoan architecture. Barnes and Green (2008) discuss the difference between these two houses; Buck, Krämer (1994) and Allen cover their construction in detail.

3. It is interesting to note the structure of On Adams House in Paradise, which begins with Le Corbusier and then recedes to the $18^{\text {th }}$ century, the Greeks and Romans, until we arrive at the Hebrew religious rituals. These are compared with the waninga totems of the Aranda aborigines of Central Australia. It uses historical moments in the primitive hut's many returns, like notches in the string of time to trace a lost beginning.

4. For Samoan terms, refer to glossary.

5. In this context, Samoan thought includes the work of Aiono Fanaafi, Tui Atua, Aumua Simanu, Albert Wendt and others. It has links with Pacific thought in general through the work of Futa Helu, Epeli Hau'ofa, Kona Thaman-Helu and 'Okusi Mahina in Tongan; Mason Durie, Witi lhimaera and Ngahuia Te Awekotuku in Māori; John Pule in Niuean; Vilisoni Hereniko in Rotuman. 
"View of the inside of the meeting house of Apia" - Interieur de la maison publique d'Apia, Ile Opoulou. drawing by Goupil; lithograph by P. Blanchard, in J.S.C. Dumont d'Urville, Voyage au Pole sud et dans l'Oceanie, Paris, Gide, 1848 , plate 84

6. Marcel Mauss uses the term habitus (Mauss 2006: 80) to refer to techniques of the body. The point here is that the body in Samoan thought is seized and taken up by something other than itself.

7. Architecture belongs to a technical system performed and perpetuated by the Tufuga-fau-fale builders guild (Krämer 1994: 265; Buck 1930: 85-87). Bernard Stiegler developed the concept of an 'epiphylogenetic system' to describe the emergence of technics (tools and systems of know-how) as an external artificial mnemonic apparatus, through which people and tools share a memory. Architecture performs exactly this role in inscribing, recording, marking and fabricating space: a technical system which performs (Stiegler 1998: 17). This can be seen in the way tools were treated as being of sacred origins by the Tufuga and Tohunga cults of Polynesia. The cults were secretive about their trade, especially in relation to the tools; in one story, the tufuga fled when discovered in the act of gnawing timber with their teeth (Stuebel, 1976: 14-17).

8. For writings on the $v \bar{a}$ see Wendt (1996), Mageo (1998: 8I) and Tuagalu (2008: 107-126).

9. Sheehan reads Heidegger's finitude as 'co openness', or 'co-extensive with finitude,' as the "first gift which makes it possible and necessary to take-as and to understand 'is' $\ldots$ the basis for all forms of interpersonal togetherness, the eyeball-to-eyeball of political struggle, the face-to-face of moral obligation,

... what lets us live a co-history, ...living and working together and making communal decisions" (Sheehan 200I: 200).

10. Mamalu goes hand in hand with pa'ia and is often cited as having dignity and sanctity (Tcherkézoff, 2005: 254).

II. See Albert Wendt's important discussion of the $v \bar{a}$ as a concept encompassing Samoan culture especially in relation to tattooing (Wendt 1996).

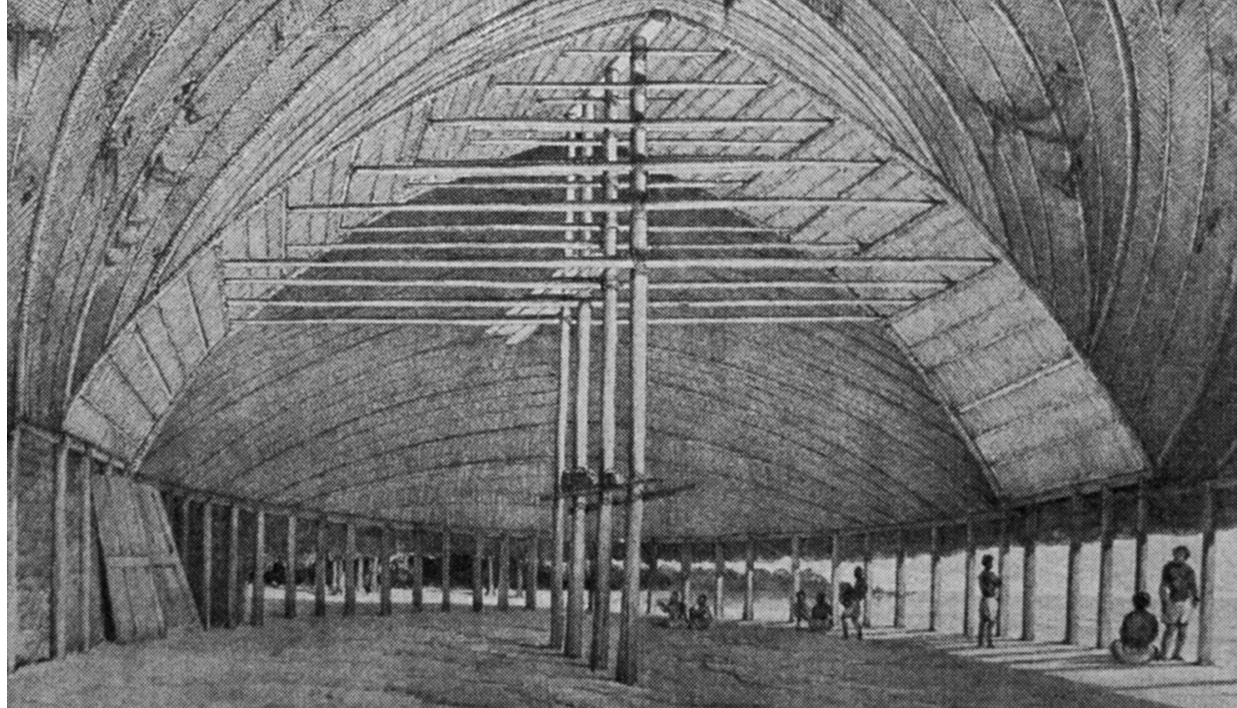

\section{Panoptic habitus $^{6}$}

In Samoan thought, architecture is related to performing a material manifestation of 'space-towards-the-ancestors,', marked by an opening, the $v \bar{a}$. The $v \bar{a}$ is a space-event enacted by the fa'amatai, or gathering of family chiefs in the circle of the fono (council; Tofaeono 2000: 32). ${ }^{8}$ This $v \bar{a}$, or co-openness, ${ }^{9}$ located at the centre of every gathering, every sociality, structures Samoan identity. Mamalu, ${ }^{10}$ a concept related to this co-openness, is a singular panoptic gaze at the core of Samoan values. It inhabits the centre of social space and exposes and discloses the being of tagata (human); being human in Samoa implies an exposure of tagata to this co-openness of the $v \bar{a}$. As will become evident, everything must go towards this centre, and be lit up, to have any meaningful existence in the social world of Samoans. ${ }^{11}$

According to Serge Tcherkézoff, the $v \bar{a}^{\prime} \mathrm{s}$ co-openness is formed by the council of matai (chiefs), the "circle of fa'amatai" (the circle of becoming-matai). An eloquent visual example is the way in which people throughout Western Polynesia arrange themselves when they come together in a socially recognised group: they form into circles. Samoans speak of a 'sacred circle' (alofi $s \bar{a}$ ). This figure is well suited to showing a single belonging: in which each person sits around the circumference and at the same distance from the centre, which is the place of the divine. Yet the circle is oriented, simultaneously and contrary to the geometry we are familiar with, by axes of value which divide the circumference into clearly differentiated arcs. Within these arcs, each point is different from the next. In Samoa, these points are represented by the posts holding up the conical roof of the ceremonial house, itself comprised of a circular base, a circle of posts and a roof, without internal partitions (2005: 246).

This "circle of fa'amatai" is a transposition of the first fono held between the god Tagaloa-a-lagi and the architects of the first house (Krämer 1994: 259; Buck 1930: 85). The prefix $f a^{\prime} a$, like the Māori whaka (Biggs 1969: 102-103), denotes an action or a manner of becoming, so that fa'amatai means "becoming-matai". Mata (literally: eye, point, spot, or centrality) is related to the word amata, which is "to-begin" or "to-become". To orient oneself towards the ancestor is to become $a-m a t a$, or to be at the centrality of becoming-ancestor. Thus, in Polynesia, the concept of space-time suggests that we move towards a future by orienting our being to a collective opening that continues with us. Some call it the past, but I suggest that this past is not static but an ever moving ancestor-duration, which is always already woven within us and endures within our becoming. This constellation is commonly explained by the metaphor of walking with our backs to the future as we face the past (Whiteford/Barns 1999: 214; Salmond 1978: 10; Metge 1967: 70). This conception places time in the service of the ancestors. Together, we and they mark and make time, making it evolve as duration. It opens and 


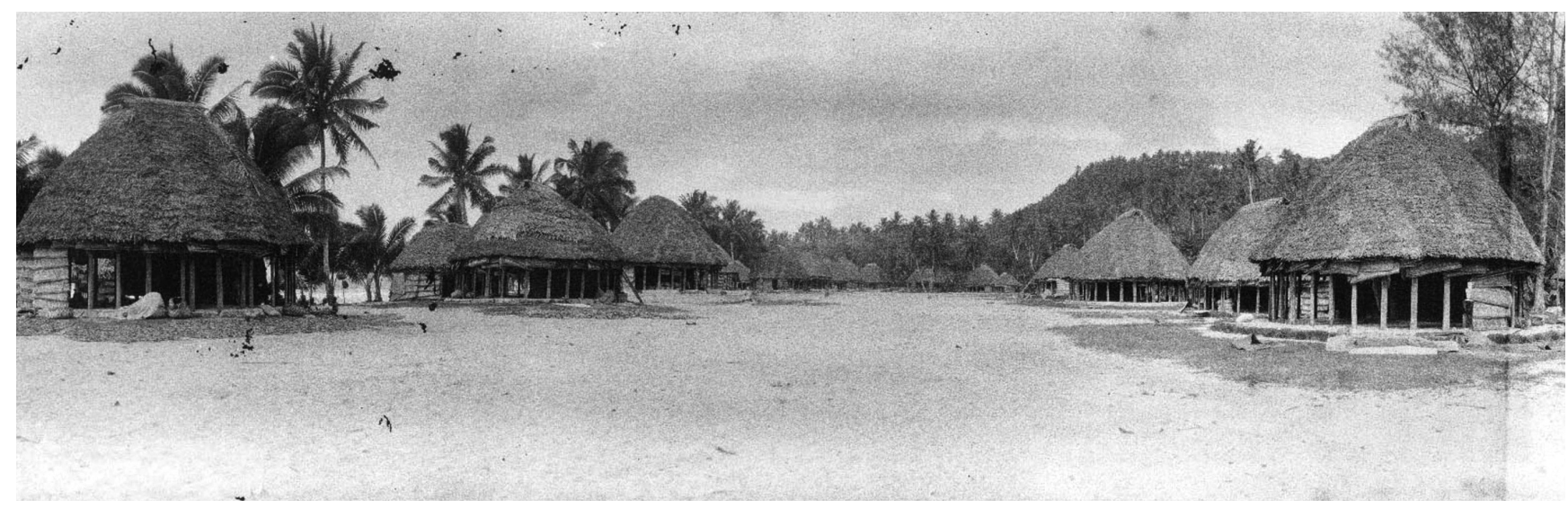

contracts relative to our engagement: this is the meaning of the Polynesian word for time - tau. Outside our involvement, time becomes $t a$, unmediated action. Therefore, a collection of individuals gathered in space is a neighbourhood of ancestor-becoming, a duration - woven time - within the co-openness of the $v \bar{a}$. The Samoan choreographer Lemi Ponifasio ${ }^{12}$ suggests that rituals readily activate this $v \bar{a}$ opening and, if this is the case in performance, then it should be added that architecture is, as its setting, the instrument of this opening.

Architecture, in Samoa, ${ }_{13}^{13}$ solicits the art of building from the Tufuga cult, to allow the dwelling to appear - to prise open the $v \bar{a}$, and delay/defer the ancestorbecoming in the present, ${ }^{14}$ thereby forcing the ever-moving present into the coopenness of the $v \bar{a}$. The trick that Samoan architecture must perform here is not the necessary protection of the ancestors, as some might imagine, not the making of temples to house and delay the ancestors - but the opposite. Architecture as instrumental agency must expose the ever-moving present to the becoming-ancestor to submit the "now" to the panoptic gaze of the ancestor, to light it up and let it be enveloped by mana. Building is an apparatus for the becoming-ancestor.

\section{Tufuga and technical culture}

According to Rykwert, the idea of reconstructing the original form of building was deeply connected with the religious life of people. The hut, as the place where the divinity was worshipped, elaborated an "identification with a body, ... human or some perfect supernatural one" (1995: 83), which reveals "a volume which man could interpret in terms of his body, ... an exposition of the paradisal plan, ... [which] established him at the centre of it" (Rykwert, 1981: 190). In Western thinking, the human body has served as the manifestation of a divine plan and canonic proportional system of construction since antiquity. ${ }^{15}$ Building was supposed to reveal man as he is: the abstracted ratio that gives rise to the edifice itself.

The human body also plays a part in Samoan architecture but, rather than a universal ratio embodied within the building itself, the body becomes immersed/ seized within the 'co-openness' emanating from the centre of the architecture. The body must not first be fused to the building for architecture to exist, because space already determines a particular ratio: demarcating a circular or oval form, which it must provide for the circle of the fa'amatai. An important point in Samoan thought is that the body is a divine agent of one's ancestors. Architecture is something required, but is other to the co-openness - the building is not the agent of the ancestor: the body is. Architecture is a technological system that materialises the tau (ordering) of space..$^{16}$ Tau means counting, recitation, order-
Top: Village Malae.

Photo: Thomas Andrews

12. "For example, Samoan dance is not so much just the correct execution of a movement, but more importantly your appropriate state of awareness to the multiple relationships. Awareness is valued over the artistic. Knowing dance is knowing how to sit, walk and talk - to understand your relationship with humans and all things." (Ponifasio 2008)

13. I refer specifically here to the faletele (oval council house) and the faleafolau (long council house) because they are made to the configurations of the fono council of the fa'amatai and are generally accepted as the first order of Samoan architecture. Barnes and Green (2008) discuss the difference between these two houses; Buck, Krämer (1994) and Allen cover their construction in detail.

14. Delay and/or defer by way of an epiphylogenetic system, an organized inorganic system that concerns tools and the technology of construction which activate a memory exchange between the human body and technology (Stiegler: 140). As well as being guardian of the knowledge of building, the Tufuga cult was also concerned with the technological culture of art-making in Samoa, tattooing, boatbuilding and navigation (Krämer 1995: 239; Handy: 15, 22).

15. Building was supposed to reveal man as he is: the abstracted ratio that gives rise to the edifice itself. Rykwert explores this later in The Dancing Column: On Order in Architecture (1995).

16. Koskinen explores tau as a protoPolynesian word related to recitation and song that bring things to life (Koskinen 1967: 34-40). Tau is to count, to recite, to order, to make time. All of this is also the task of the Tufuga-fau-fale. The Tufuga-fau-fale has to expose the materiality of the world - its organised matter - to the overwhelming glare at the centre. 
17. It is important to note Allen's analysis of Samoan social space, which suggests a formal order that divides the materiality of the world into smaller compartments, "like a pomegranate, a macrocosm which contains within it many macrocosms, the seed that possesses the potential for production" (Allen: 3 ). She suggests that is how architecture comes about in the work of the Tufuga: "Their work, which results in the divided space we call architecture" (157).

18. These were the four parts of their role discussed in Buck (87-96) and Krämer (1995: 266-269).19. According to legends the Tufuga cult was the first to be in possession of tools (Krämer 1994: 543).

20. I use Deleuze and Guattari's terminology here because of the equation that the body (tino) "is" the face of the ancestor (foliga) in Samoan thought (Tui Atua 2009: 71-72): a face does not belong to a single individual but as a membrane/ tissue connected to the ancestor and distributed through the familial tissue, much like the complex machine of faciality as a signifying system in Deleuze and Guattari. See the diagram of Maritime Subjective Authoritarian Face (after Tristan and Isolde) where the face can become a reference point for the system of relations. "A face refers back to a landscape, ... recall[s] a painting, ... a piece of music" becoming a "faciality line, a consciousness line, a passion line etc." (Deleuze \& Guattari, 185)

21. Rykwert's analogy of Adam's house in Paradise suggested that since Adam was exiled from paradise he had to build the first dwelling to protect himself and his children from the elements (II8).

22. Tagaloa sent down the Tufuga cult to build a boat for his daughter Mataiteite (Steubel: 14-17). ing, making time, and this was the task of the Tufuga-fau-fale. The Tufuga-fau-fale has to expose the materiality of the world - its organized matter - to the overwhelming glare at the centre of all spectacles.

Architecture as a technical system submits nature and its materiality to the co-openness of the $v \bar{a} .{ }^{17}$ Traditionally, to achieve this, the Tufuga had to negotiate, evaluate, manipulate and fabricate. ${ }^{18}$ Negotiate: this began with a fale agai (contract) between the Tufuga and Taufale (the chief commissioning the house) guaranteeing payment and delivery of goods between the builders and family. The contract bonded the Tufuga cult to the family during the construction period. Fale is house; agai means "a-facing-with-one-another". Together, these words denote a bond consummated during the kava drinking ceremony between the parties, after which the guild members became extended family members and were housed and fed by the family. This ceremony usually took place at the fono discussed above. Evaluate: the selection of materials and timber for the house was made only after a formal contract or fale agai had been agreed. The Tufuga chose the appropriate timber for the house, but the felling was left to the family. The builders took over responsibility when all materials arrived on the site (Allen 1993: 109-110; Handy 1924: 15). Manipulate: all building components were shaped and dressed with notches and grooves for joints before they were assembled. This was predominantly the Tufuga's and apprentice's task, as it concerned shaping and cutting with tools - and tools were part of their responsibility. A well-dressed house was synonymous with the work of the Tufuga cult. The manufili (scaffolding) was erected at the centre, around the central posts, and aided in the shaping of the house before all the components were fixed and lashed in place. Fabricate: locating the manufili scaffolding at the centre of the site allowed the builders to shape the building from the inside out. The scaffolding acted as a prop and ladder structure while the house was being shaped, joined and lashed together. The last parts to be made were the outer posts, the thatched roof and the paepae (house platform). Since no tools were required for these final tasks (except the lashing of the thatch to the roof and the final trimming of the excess thatch), they were carried out by the family. ${ }^{19}$ It is clear from evidence in Buck and Krämer that the cult's contribution to building was mainly in tasks that required tools: the shaping of architectural components and determination of the overall form of the building. Tufuga dealt with those parts of the house which were generally referred to as being dressed or teu.

According to the Samoan creation story Solo o le V $\bar{a}$, the Tufuga were descendents of the progenitor Tagaloa-a-lagi and responsible for house and boat building (Fraser, 1897; Krämer 1994: 539-544). The story recounts how the cult members were present at the very first fono convened by Tagaloa-a-lagi, the supreme god of the Samoans, in the ninth heaven. Some 1000 Tufuga attended and were served the first cup of kava (Fraser 1897: 28; Krämer 1995: 543). The Tufuga cult was thus accorded the status of agai o tupu (companion of gods and kings). Agai comes from the word feagaiga (facing together); it was this first open faciality that oriented the cult to the progenitor. ${ }^{20}$ Not only were the Tufuga in charge of making form appear, these skilled craftsmen, whom we might recognise in a Rykwertian sense as the clan of Adam, ${ }^{21}$ were expected to keep the gods and kings company. The Tufuga cult became known as Sa Tagaloa (clan of Tagaloa).

The cult was sometimes granted permission to descend to the islands of Upolu, Savai'i and Manu'a to construct a number of houses and boats, ${ }^{22}$ until a few of 
them decided to build a house for the Tui Manu'a - king of Manu'a. This angered the god, who destroyed the house and banished the cult from heaven (Fraser 1897: 28). The forbidden house was a faletele (council house) called Faleula (red or crimson house; Krämer 1994: 528; Buck, 1930: 84), which was thatched with red feathers. Some believed that the posts were also stained with sacrificial blood. By all accounts, this first house lacked all the rustic naturalism of the primitive hut. It was not a supposed cradle of mankind, but a well-dressed, bright red house that gathered together the first technicians of the Samoan world.

Exiled from heaven and without their traditional home, the cult roamed Samoa, offering their skills to the highest bidder. ${ }^{23}$ Its members were - and still are - known for their wanton reputation of moving from patron to patron to be housed, fed and entertained by anyone who wished to acquire their services. Being descendants of a god and companions of kings and princes, these men were afforded respect but were also always seen in a special category of the fallen.

\section{Smoothing and clearing: the light of the world ${ }^{24}$}

Members of the Salemalama Tufuga clan were present at the fono meeting in the ninth heaven (Buck 1930: 84; Handy 1924: 15). ${ }^{25}$ In the A'ana district, the title Salemalama was thought to have originated from the first house built on Upolu, in the village of Faleolo, for the Tui A'ana (King of A'ana). Members of the Sa'anapu Tufuga clan believe the house was built with driftwood found by the taupou maiden Lemalama on the seashore, who suggested that they be used by the craftsmen to construct a house for her father Tui A'ana Lilomaiava. The builders' guild was given the title Salemalama (family of Lemalama) thereafter. ${ }^{26}$ This first house was named Faleolo, ${ }^{27}$ because the sea had smoothed the timber (olo means the act of smoothing, or the rasping of something, for instance when timber is being dressed; Pratt 1883: 94).

The Savai'ian version of the story proposes that the Tui A'ana sent for the Tufuga brothers Segi, Leifi, Moe and Solofuti from Fitiuta to build his house. ${ }^{28}$ This became the first house to be dressed, olo. Because the men wore no clothes during construction, they were forbidden to erect the house during the day. Therefore, the house was built at night and at daybreak the house would miraculously appear in various stages of completion (Refiti 2007: 36-37). The Tui A'ana bestowed the title Salemalama upon the brothers at the final feast. It is important to note that the Tufuga are experts in manipulating raw materials and bringing the materials to an openness and display, clearing away and presenting the materiality of the world towards the openness of mamalu inside the matai circle. ${ }^{29}$ The Tufuga expose things to this co-openness to make them malama - whitened or illuminated. Therefore, Salemalama, the title of the first architects, can be read as "the one who exposes the world to the light of the ancestors".

If we look at the name Salemalama itself, we find another meaning. $S a$ (sacred or forbidden in terms of tapu), and malama (light) suggests the meaning "forbidden to see the light of day". ${ }^{30}$ This reinforces the notion that things oriented towards the ancestors are to be exposed/disclosed and made light by being stripped and rubbed, as in the Faleolo house, stained and thatched with redness, as in Faleula, the crimson house, the first house that was brightly lit in heaven like a beacon.

There is an interesting relationship here with tools and tooling that the Tufuga activate by way of to' $i$ (felling the timber with axes) and the subsequent fash-
23. Tufuga were involved in houses made especially for overseas consumption. (See Engels-Schwarzpaul and Wikitera in this issue, p.42)

24. The "light of the world", a basic metaphor for divinity in Egyptian and early Christian thought, was later associated with the European Enlightenment and employed by philosophers such as Husserl, Heidegger and Henry. Being exposed to light, or coming into light, however, is a figure of thought used much more widely, as, for instance, in Samoa.

25. There are 10 heavens in Samoan cosmology, Tagaloa-a-lagi the progenitor resided on the tenth, the Tufuga cult built the first house Faleula on the ninth, but they lived in the eighth heaven (Turner: 3-9; Fraser: 25-27).

26. This is the belief of the Tufuga clan in Sa'anapu, Upolu, relayed to me by Matua Faiva Faivaaiga Kilifi luma in an interview in February 1998.

27. An old village, Faleolo, inland from the Samoan International Airport in the A'ana district, was the most probable location of this house.

28. Fitiuta is located on Manu'a Island where the Tui Manu'a - king of Manu'a - resided. There is a view that Fitiuta in ancient times was actually Fiji.

29. The malumalu, a smaller building type which did not differ greatly from the faletele, was set aside in every village (later replaced by the Christian chapel) for housing village gods in the form of objects, e.g. stones, baskets, sennit strings. Worship was usually carried out in the family faletele, though, where the matai chief would act as a priest. (Turner 1984: 240; Freeman 2004: 133)

30. This was the belief of Matua Faiva Segi Tutufaiga of Savai'i, who also suggested that the house was located in Faleolo. (Refiti, 2007: 36) 
31. See Okusi Mahina's work on the vā and its relationship to $t \bar{a}$ in Tongan and Pacific art-making which shares a close relationship with the Samoan notion of vā. (Mahina 2002)

32. The work of Ka'ili and others have made what I believe to be a mistaken assumption that Tauhi le vā equates to Teu le vā (Ka'ili 2005 \& 2008). Teu in Samoa happens before and in front of the circle of fa'amatai; tauhi (Tongan), which is tausi in Samoan, happens outside this circle, therefore it cannot be teu; the wife of a matai chief is known as a tausi and she sits outside and away from the circle of fa'amatai.

33. See note 24 .

34. Rykwert makes an analogy to this in Le Corbusier's primitivism. (1981: 15-16) ioning and dressing with scrapers and adzes made from shells and rocks. The building is broken up into smaller components, so that every detail is worked and smoothed by the tools. With joints and grooves completed, the final work is a gathering of all components to be lashed in place using sennit ropes. Sennit is made of coconut and other natural fibres that have been bleached in the sun and then woven into rope.

One might be curious why so much attention is paid to stripping the timber of its bark and making it smooth, when the more natural state of the timber would give the house a rusticated appearance blending in with the green and lush surroundings. I want to suggest here that the function of smoothing is related to the Samoan notion of teu. Teu has a number of interrelated meanings: "to adorn", "to embellish", "to save or to store up" (Pratt 1893: 307), and "to cultivate" when used in the plural teuteu. When applied to craft, teu has to do with smoothing, bleaching and tidiness. Teu is commonly associated with fine mats. The finest of fine mats, 'ie sina or 'ie toga (Krämer 1995: 342; Tcherkézoff 2004: 167), are made from pandanus leaves soaked in sea water and then left to bleach in the sun; they become lighter in colour, or sina (white). A mat made from these materials by an expert weaver is considered the most precious of treasures and becomes the most revered form of teu that exists.

Teu happens in the context of relationships invoked by the motto "ia teu le va" (Wendt 1996), which means adorn and embellish the $v \bar{a}$ and the networks of coexistence that are housed by architecture. ${ }^{31}$ At the centre of the architecture is a clearing, which allows a co-openness of the $v \bar{a}$ towards the ancestors. Within the circle of the fa'amatai is the mamalu (dignity) and pa'ia (sanctity) of the community. From here emanates the highest form of mana. To teu is to make things tatau (proper), to make them appear in a display before and 'in-front' of this openness of the community. In the context of "teu le v $\overline{\bar{a}}$ ", all things placed before the community demarcate and fix space towards the ancestors in an orientation, a faciality. What happens immediately behind or away from this openness is "tausi le vā (to support or look after the $v \bar{a}$ ), which occurs outside the great openness. ${ }^{32}$

The faletele was considered to be the most important stage for teu (embellishing) the $v \bar{a}$ of the circle of fa'amatai. In its construction, bleaching was an important technique. The making of space, by extension, was oriented towards the production of things that were white, smooth and open, because these were to be placed before the circle of the fa'amatai, towards the ancestors. Teu was also an obligation to perform the rite of clearing, making order from the materiality of the world; to perform is to teu in readiness, and in readiness something is stored up, which is the other meaning of teu: storing and saving. Architecture has to perform, or teu, the co-openness of the $v \bar{a}$.

\section{Captive whiteness}

The architecture of the primitive hut is premised on man's exile from Paradise: he is thrown into the "light of the world", ${ }^{33}$ and this gives rise to a future for architecture, which revolves, represents, repeats and progresses without being able to still a lingering nostalgia. ${ }^{34}$ In Western metaphysics, the self appears in the world as a being "showing itself ... becoming visible in the light ... the there of an outside ... in the world" (Henry 2008: 84). The exterior nature of the "light of the world", which, as a source of understanding, distinguishes objective thought, 
is reversed in Samoan thinking. ${ }^{35}$ Light, as knowledge and understanding in Samoan thought, is not something that comes to us from outside. Rather, it appears as a divine ( $p a^{\prime} i a$ ) force emanating from an interiority or, more precisely, from a centrality, as discussed above, a co-openness at the heart of the circle of fa'amatai. To its glare, objects and the materiality of the world are exposed. Architecture, with its task of teu, fashions things towards this centrality, which radiates beauty and order. Following Marshal Sahlins, Tcherkézoff contends that Polynesian notions of beauty emanate from those of chiefly rank: "Such beauty is properly called divine, for ... it causes things to be seen" (2004: 122).

What is a source of light if this source finds nothing to illuminate? What is a god without a world that he has created? ... A light is not seen unless it rests on some being or on some object. In the same way a Polynesian chief without dependants has no existence. But the relationship is directional: one of the participants is the source of light and the other becomes visible because he is illuminated. The dependant finds a way to participate in life (the world of 'light' Ao) solely through his relationship to the chief: he is then illuminated ... The same goes for the chief in relation to the gods. (124)

Tcherkézoff describes the figures in the circle of fa'amatai as a "source of light", because they are incarnations of gods, heirs to the legacy and names of the ancestors (124). Objects exposed or touched by this very sacred circle become measina, luminous-white things. Measina, like the Māori tāonga, are highly treasured persons or things. The three most important ones in Samoan thought are, first, fine mats, which are named in relation to a prominent woman of a matai family. Secondly, Faleula, discussed above as the first council house built in heaven and thought to be the most important measina in origin stories. ${ }^{36}$ Measina is now used to describe traditional knowledge and art more generally, but this was not the case before European contact. Then, the concept was used only to denote things related to women of important stature: they were thought to be related to the origin of light and whiteness. ${ }^{37}$ Therefore, thirdly, the taupou (ceremonial virgin) is presumed to possess all virtues of light and whiteness. Because of her value, she was confined to the interior of the faletele, attended to by young female assistants and chaperoned by the elderly women of the village. She was the main tenant of the faletele: her whiteness was to be preserved under its arched roof. Krämer noted that:

[The taupou] normally does not have to subject herself to coarser work ... That is why ... Sina (white) is the name of such elevated girls. That also accounts for the slender well cared for hands and the soft velvety skin, constantly kept clean and fragrant by the use of fine perfumed oil prepared especially for her. (1994: 34)

The taupou, as measina, is to be cared for and cultivated as teu (adornment and saving); she is to be dressed and chaperoned for the cultivation of social manners. Confined to the interior of the house, she becomes a captive of the circle of matai, and paradoxically this will, in turn, make her increase the finesse and lightness that are required of measina. Measina, as the bleaching and whitening of the materiality of the world, turns things and people into treasures, to be presented and touched and exchanged by the ancestor-beings that sit at the circle of fa'amatai.
35. See Michel Henry's radical revision of metaphysics in his Material Phenomenology, which breaks away from representation (exteriority) as a mode of articulating the self; he advocates a radical immanence (interiority) based on affectivity - a self for itself. (Henry 2008: 130)

36. Faleula is now used to describe the gathering of important matai of all of Samoa.

37. This was the meaning of the name Sina (Hina, Tina, Hine), which is the most common name for the heroine of Polynesian mythology. In these stories Sina is usually described as a young virgin highly prized for her virtues and courted by gods, men and creatures - the most famous in Polynesia being the story of Sina and the Tuna. 
38. I have discussed this central space elsewhere as being a forked centre. (Refiti 2008)

39. Present-ness becomes radical exteriority, which complicates a simple reading of the binary opposition between interior and exterior. (Richter 2007: 119)

40. The other meaning of teu is "to put away" (Pratt) or to store away when items pertaining to teu are not on display.
At the house's mata, or central interior focus, people and things are exposed to the co-openness of the circle of fa'amatai. The most central spot, the inner-most part of the house is, paradoxically, also the most public of places. ${ }^{38}$ Interiority becomes externalised, everything is drawn towards, and exposed in, this grand internal openness. However, this interiority is externalised again: space does not recede into an interior but is thrown back onto the surface of the world. So is time: the past, the time of the ancestors, is not located in the vanishing horizon of a time that was, but takes place in the present. It endures in what Albert Wendt describes as the "ever-moving-present" (1996). ${ }^{39}$ This is the mode in which space and time function in Samoan architecture. The house cannot be fixed in time.

The matai or chief is the spatial and temporal manifestation that enables ancestors to be here in the present. The faletele and the mythical Faleula are one-andthe-same house, an architectural construct that teu the present towards the ancestor. Teu, in this house, occurs first by providing, storing and saving the time of the ancestors in its interior, making the circle of fa'amatai possible under its roof. Secondly, it displaces and discloses this time in the present. The world is adorned, from the centre to the periphery, by lighting it up and obliterating the shadowy materiality of the world.

\section{Architecture: central openness}

So, what role does architecture perform? In Samoan thought, architecture is first and foremost an apparatus, which sets out and sets in motion the becomingancestor. As a technical apparatus, it performs by locating points, or situatedness, in the ever-moving present and articulating time through space. The simultaneity and ubiquity of the ancestors is momentarily focused and housed. Points (mata) alone fashion the plan of the house: they are the posts that denote ancestors and become the generator of space. The materiality of the world is corralled around these points, shaping a hut, a building. The building is measina, of whiteness. It is also teu, of smoothness. By being smoothed and whitened, the materiality of the world comes to face the ancestors. The architectural apparatus performs by teu. ${ }^{40}$

A collection of individuals gathered in space is a neighbourhood of ancestorbecoming, which each must always orient to the other in an open faciality, within the co-openness of the $v \bar{a}$.

Houses orient us. In Samoa, Faleula, faletele and faleafolau fix the orientation of the world, they force the body to orient itself to a central openness. There is something in the centre, which will never escape our gaze: rather, it will seize our gaze. Samoa's primitive hut allows matai to be gathered close to this central openness. One cannot get any closer to the centre when one sits in the faletele in a group. One's tua (back) must rest on a post, the ancestor, so that one's back is concealed, or, to put it in another way, one's back is taken. With one's back taken, one is now opened up and made into a face - made to face other faces, one's companions in the circle. Openness, now, is not something located elsewhere, but right there, on the faces of the others. All are oriented towards the ancestors. In establishing this orientation, architecture plays a particular role. It ensures, through the circulation of time and space, that origins are articulated and dispersed. Origins are everywhere, all the time. 


\section{Glossary}

\begin{tabular}{|c|c|}
\hline agai & to face or head towards something or another person \\
\hline alofi sā & sacred circle \\
\hline fa'amatai & $\begin{array}{l}\text { hierarchy of ancestral names and titles associated } \\
\text { with rule and government of Samoan society }\end{array}$ \\
\hline faleafolau & long council meeting house \\
\hline fale agai & building contract \\
\hline faletele & oval or round council meeting house \\
\hline Faleula & $\begin{array}{l}\text { ritual name of the first house, meaning } \\
\text { the "crimson house" }\end{array}$ \\
\hline feagaiga & a sacred covenant, usually between brother and sister \\
\hline fono & a council meeting \\
\hline malama & light, illumination \\
\hline mamalu & dignity \\
\hline manufili & building scaffolding \\
\hline mata & eye or centre \\
\hline matai & an individual vested with an ancestral name \\
\hline measina & treasure or a thing of utmost value \\
\hline olo, olo'olo & smoothing, honing or rasping \\
\hline$p a^{\prime} i a$ & sanctity \\
\hline paepae & house platform \\
\hline Salemalama & name of a branch of the builders' guild \\
\hline Sa Tagaloa & ritual name for the builders' guild \\
\hline Tagaloa-a-lagi, Tagaloa & Samoan god \\
\hline to'i & axe, adze \\
\hline tāonga & Māori word for treasure \\
\hline tapu & sacred or forbidden \\
\hline tatau & proper or apt \\
\hline tau & to arrive or to count, also time of the seasons \\
\hline teu & adorn or embellish, also to put or store away \\
\hline Tufuga, Tufuga-fau-fale & builders' guild \\
\hline tua & back or behind \\
\hline$v \bar{a}$ & $\begin{array}{l}\text { opening between or space between, to } \\
\text { denote relationships }\end{array}$ \\
\hline
\end{tabular}




\section{References:}

Allen, A. (1993). Space as social construct: The vernacular of rural Samoa. Unpublished dissertation for the degree of Doctor of Philosophy, Colombia University, NYC.

Barnes, S. \& Green, R. (2008). From Tongan Meeting House to Samoan Chapel. The Journal of Pacific History, 43:1, 23-49.

Biggs, B. (1969). Let's Learn Māori: A Guide To The Study Of The Māori Language. Wellington: A.H. \& A. W. Reed.

Buck, P. (1930). Samoan Material Culture. Honolulu: Bernice P. Bishop Museum Bulletin.

Davidson, J. (1969). Settlement Patterns in Samoa before 1840. Journal of the Polynesian Society, 78: 44-82.

Deleuze, G. \& Guattari, F. (1987/2007). A Thousand Plateaus: Capitalism and Schizophrenia (B. Massumi, Trans.). Minneapolis, London: University of Minnesota Press.

Fraser, J. (1897). Solo o le Va: Folk-songs and myths from Samoa. Journal of the Polynesian Society, Volume 6, No. 1, p19-36.

Handy, E. \& Handy, W. (1924/1971). Samoan House Building, Cooking, and Tattooing. Honolulu: Bernice P. Bishop Museum Bulletin 15.

Henry, M. (2008). Material Phenomenology (S. Davidson, Trans.). New York: Fordham University Press.

Freeman, D. (2004). On missionaries and cultural change in Samoa. The Journal of Pacific History, 39: 2, 241-250.

Ka'ili, T. (2008). Tauhi Vā: Creating Beauty Through the Art of Sociospatial Relations. Unpublished dissertation for the degree of Doctor of Philosophy, University of Washington.

Ka'ili, T. (2005). Tauhi Vā: Nurturing Tongan Sociospatial Ties in Maui and Beyond. The Contemporary Pacific, Vol. 17, No. 1, University of Hawai'i Press, p83-114.

Koskinen, A. (1967). Linking of Symbols: Polynesian Patterns 2. Helsinki: The Finnish Society for Missionary Research.

Krämer, A. (1994/1999). The Samoan Islands: Vol. 1, (T. Verhaaren, Trans.). Auckland, NZ: Polynesian Press.

Krämer, A. (1995). The Samoan Islands: Vol. 2, (T. Verhaaren, Trans.). Auckland, NZ: Polynesian Press.

Mageo, J. (2001). The Third Meaning in Cultural Memory: History, Identity, and Spirit of Possession in Samoa. In J. Mageo, (Ed.) Cultural Memory: Reconfiguring History and Identity in the Postcolonial Pacific. Honolulu: University of Hawaii Press.

Mageo, J. (1998). Theorizing self in Samoa: emotions, genders, and sexualities. Ann Arbour: University of Michigan Press.

Mahina, O. (2002). Tufunga Lalava: The Tongan Art of Lineal and Spatial Intersection. In S. Rees (ed.) Filipe Tohi: Genealogy of Lines Hohoko e Tohitohi. New Plymouth, NZ: GovettBrewster Art Gallery.

Mauss, M. (2006). Techniques, Technology and Civilisation. New York \& Oxford: Berghahn Books.

Metge, J. (1967/1976). The Māoris of New Zealand: Rautahi. London: Routledge \& Kegan Paul.

Ponifasio, L. (2008). NZ Listener, February 2-8 2008 Vol. 212, No. 3534.

Pratt, G. (1893/1984). A Grammar and Dictionary of the Samoan Language. Papakura, New Zealand: R. McMillan Publisher.

Refiti, A. L. (2008). Forked Centre: duality and privacy in Polynesian spaces and architecture. Alternative: An International Journal of Indigenous Peoples. Vol. 4, Issue 1, p97-106.

Refiti, A. L. (2007). The Origin of Samoan Architecture. In E. Lehner et al (Eds.), Das Architektonische Samoas. Vienna: Neuer Wissenschaftlicher Verlag, p32-37.

Richter, G. (2007). Thought-Images: Frankfurt School Writers' Reflections from Damaged Life. Stanford, California: Stanford University Press. 
Rykwert, J. (1995). The Dancing Column: On Order in Architecture. Massachusetts \& London: The MIT Press.

Rykwert, J. (1981/1997). On Adam's House in Paradise: The Idea of the Primitive Hut in Architectural History. Massachusetts \& London: The MIT Press.

Sheehan, T. (2001). A Paradigm Shift in Heidegger Research. Continental Philosophy Review, 34, pp.183-202.

Salmond, A. (1978). Te Ao Tawhito: a semantic approach to the traditional Māori cosmos. The Journal of the Polynesian Society, 87: 5-28.

Stiegler, B. (1998). Technics and Time 1: The Fault of Epimetheus (R. Beardsworth \& G. Collins, Trans.). Stanford: Stanford University Press.

Stuebel, C. (1976). Myths and Legends of Samoa: Tala o le Vavau. Wellington, Sydney \& London: A.H. \& A.W. Reed.

Tcherkézoff, S. (2005/2008). Culture, Nation, Society: Secondary change and fundamental transformations in Western Samoa. In S. Tcherkézoff \& F. Douaire-Marsaudon (Eds.), Changing South Pacific: Identities and Transformations. Canberra: ANU E Press, p256-257.

Tcherkézoff, S. (2004). First contacts in Polynesia: the Samoan case (1722-1848): Western ååmisunderstanding about sexuality and divinity. Christchurch, NZ: Macmillan Brown Centre for Pacific Studies.

Tofaeono, A. (2000). Eco-Theology: Aiga - The Household of Life, A Perspective from Living Myths and Traditions of Samoa. Erlangen: Erlanger Verlag für Mission und Ökumene.

Tuagalu, I. (2008). The heuristics of the vā. Alternative: An International Journal of Indigenous Peoples, Vol. 4, Issue 1, p107-126.

Tui Atua, T.T.T. (2008). More on Meaning, Nuance and Metaphor. In S. Suaalii-Sauni et al, Su'esu'e Manogi: In Search of Fragrance. Samoa: Centre of Samoan Studies, NUS, 70-78.

Turner, G. (1891/1984). Nineteen Years in Polynesia. Papakura, NZ: R. McMillan Publisher.

Wendt, A. (1996). Tatauing the post-colonial body [electronic version]. Span 42-43, 1529. Retrieved March 23, 2007, from http://www.nzepc.auckland.ac.nz/authors/wendt/ tatauing.asp

Whiteford, G. \& Barns, M. (1999). Te Ao Hurihuri: New Zealand's First Time. In W. E. Pentland et al (Eds.), Time use research in the social sciences. New York: Kluwer Academic/ Plenum Publishers, p211-230. 